\title{
Issei Women and Work: Washerwomen, Prostitutes, Midwives, and Barbers
}

\author{
KELLI Y. NAKAMURA
}

I used to wake up about 3 o'clock in the morning. From that time on, even at noon, there was no time to rest. It was necessary to do my household tasks, too, and do such things as my laundry... In the afternoon I had to make preparations for the obento, and I also had to prepare for feeding them the pau hana dinner. Plus also, there were my household tasks . . For my cook work to be completed, it takes up to 8 o'clock [p.m]. ${ }^{1}$

Kame Iwatani, a retired Del Monte Corporation field worker, describes in this account her usual work day as an Issei woman in Hawai'i. Born in Yamaguchi-ken, Japan, in 1896, she arrived in the Islands in 1922 as the picture bride of Kumeiji Iwatani, a pineapple field worker. After settling in Ka'a'awa, O'ahu, with her husband, she taught sewing to the children of the camp while working in the pineapple fields. In 1924, they moved to Waimea, O'ahu where she did the laundry for the Filipino workers of the Fruits Company and heated the ofuro [public bath] for camp use. For the ten years that her husband worked as a luna [overseer] in Leilehua, she cooked meals for the field workers, and for a short time she also did housework for the plantation boss. Iwatani's life in Hawai'i, which was defined by different kinds of work, was not uncommon in the experiences

Kelli Y. Nakamura, Ph.D. is a history instructor at Kapi'olani Community College. Her research interests include Japanese and Japanese American history.

The Hawaiian Journal of History, vol. 49 (2015) 
of Issei women, as many worked multiple jobs while caring for their husbands and families.

Yet, in many Issei histories, the story of women has been limited to primarily two narratives: the reticent and subservient picture bride and the hard-working, silent plantation field laborer. Defined by their husbands and their secondary economic status, Issei women's activities in Hawai"i have not been regarded as worthy of close historical analysis. While many women arrived in the Islands as picture brides and most labored on the plantations, these simplistic characterizations do not capture the wide range of activities performed by Issei women. Although plantation owners, luna, and husbands undoubtedly exploited women who had limited language skills and alien citizenship status, other women found opportunities within the gender imbalance on the plantations. For example, as women were paid less than men, many had to take on additional "women's jobs" like laundering, cooking, and sewing to ensure their families' economic survival. Yet, the necessity of these professions on the plantations, as well as their economic success performing these duties, enabled them to have alternatives beyond field labor and to exert an influence both within and outside the family that challenged the Meiji ideal of "good wife, wise mother" (ryōsai kenbo). ${ }^{2}$ Although ideally women were to confine themselves to their homes as "dutiful wives and intelligent mothers," very few migrant women could afford to limit themselves to these two roles. Economic realities forced the majority of women to assume a third role as workers whose labor was indispensable to plantations, families, and small businesses. Issei women came to dominate certain professions such as barbering, midwifery, and even prostitution-all of which enabled them to make a living independent of their marital status and of the plantations. For Issei women, Hawai'i offered unprecedented personal and economic opportunities, transforming traditional ideas of "proper" gender roles in both America and Japan. By the necessity of engaging in different types of work, Issei women broke down the traditional divide that separated the domestic and public spheres. Thus, by analyzing the work experience of Issei women, a more nuanced understanding of a traditionally "invisible" population emerges. These women often exerted agency and initiative to transform not only their lives, but also those around them to establish the foundations of family and community life in Hawai'i. 


\section{Economic Opportunities Through Marriage}

Although most Issei women arrived as picture brides and have been defined solely by their marital status, many of them were not motivated by romantic notions of marriage or love. Nor did they marry with the expectation that they would be entirely supported by their husbands. In reality, many women were driven to become picture brides by economic factors and the promise of work in the Islands that was only permitted if they arrived as wives. During the Restricted Immigration Period (19o8-1924), married couples were allowed to immigrate but single people were barred unless they were immediate relatives of migrants or were themselves former residents of the United States. Thus, women agreed to arranged marriages to enable them to travel to Hawai'i and some even posed as kari füfu, or "temporary spouses," to gain entry into the United States or its territories to take advantage of work opportunities. As one woman explained, "I came to Hawaii as a kari füfu . . . but I hardly knew the man I came to Hawaii with. I do not even remember his name. We parted as soon as we got here."3 After their arrival in Hawai' $i$, these women applied for a divorce after a year, the required waiting period to be free from being married.

Both Issei women and men actively sought economic opportunities that were dwindling at home but were abundant in the Islands. During the Meiji period (1868-1912), Japanese government leaders decided to "enrich the country" through the importation of Western ideas and technology. However, in order to finance Japan's industrialization and modernization, officials needed to increase government revenues. In 1873, the government initiated a series of land tax reforms. The tax on agricultural land became a fixed sum, paid in cash rather than agricultural products, and determined by the legal value of the land. This change in policy enabled the Japanese government to prepare a rational budget based on the clear projection of income and expenditures so essential for economic planning. While economists and government officials applauded this new system, farmers were now at the mercy of market and weather conditions and the prices that their harvests-consisting mostly of rice-would bring. ${ }^{4}$ They were no longer protected against crop failures and bad harvests as under the feudal system of the Tokugawa period. The growth in population also exacerbated economic problems and the number of foreclosures also 
increased. ${ }^{5}$ Kame Iwatani remembers the difficulty she and her family experienced within this new economic system:

In Japan at about that time, we could not earn much money because everybody farmed. Well, when we raised silkworms we'd get loads of money because we sold the silkworm eggs. But other than the silkworm income, there was not much income so everybody wanted to come to Hawaii. ${ }^{6}$

Dreams of traveling abroad to places like Hawai'i for employment had their origins in the tradition of dekasegi rōdo, or temporary work away from home. ${ }^{7}$ This practice began in rural Japan in the early Tokugawa period, when farmers sought alternative employment to rice cultivation. Some farmers chose to add additional cash crops, such as indigo, rather than totally depend on their rice crops, while others relied on cottage industries to supplement their incomes, particularly during the winter months. Other families sent their sons out to seek jobs in urban areas, assuming that there would be more opportunities for employment. In these cases, work away from home was temporary, and when conditions improved in the countryside these workers were expected to return home. ${ }^{8}$

This custom of work away from home made migration and overseas employment an acceptable alternative to widespread unemployment; it in fact attached a sense of legitimacy to migration given the continuity of a traditional practice. ${ }^{9}$ Overseas migration, although different from its predecessor, was considered an extension of the dekasegi rōdo tradition and a solution to the economic problems in the countryside. This option of working away from home in Hawai'i was widely advertised throughout Japan to recruit potential migrants willing to be lured by the promise of higher wages, a gentle climate, and a friendly environment. ${ }^{10}$ Iwatani herself recalled, "It was said that in Hawaii, you can earn money. Everybody used to return home after making money [in Hawaii] . . . When I saw these people, I thought Hawaii had an inexhaustible amount of money." 11 As a woman, she too had heard stories of economic opportunities in the Islands but recognized that "unless you were received as a bride, you couldn't come." Thus, she and many others faced with dire economic circumstances decided to become picture brides to unknown men thousands of miles away in hopes of a better financial future. 
This expectation and desire for work among Issei women explains why shortly after the opening of migration to women, the majority of the women working on Hawai'i plantations were Japanese. By 1920 , Japanese women constituted about 80 percent of the women on $\mathrm{O}^{\prime}$ ahu plantations, and the percentage of Japanese women who worked for wages in Hawai'i was higher than other ethnic groups. ${ }^{12}$ Japanese women were concentrated in field operations such as hoe hana (weeding), hole hole ko (stripping dried cane leaves), oki ko (cane cutting), and even the strenuous and backbreaking activity of hapai $k o$ (cane loading). In 1915 , Japanese women constituted $3^{8}$ percent of all Japanese cane loaders. Yet, while women were given many of the same work assignments as men, they were paid less than their male counterparts. Japanese female field hands, for example, earned an average wage of only $\$ .55$ per day in 1915 compared to the $\$ .78$ Japanese male field hands received. ${ }^{13}$ Many women, like Iwatani, simply accepted the pay differential between men and women laborers. According to Iwatani, "it was different by about two to three cents in the old days, because pay was cheap, unlike today. . . It was made so that it [pay] was lower because we were women." ${ }^{14}$ Accepting the wage gap as inevitable, Iwatani worked at a lower pay scale than her male counterparts.

Although many women "didn't think anything" of the pay differential, the discrepancy in women's pay, which was essential to the economic survival of their families, led them to seek out other forms of employment. To explain the decision to look for additional work, one Issei woman simply stated, "Without money, of course, can't eat-must earn money." ${ }^{5}$ Thus, many women sought other avenues of revenue in industries both on and off the plantation, embracing an egalitarian entrepreneurial spirit that enabled them to work with and for different ethnicities including whites, Filipinos, Hawaiians, Koreans, and Portuguese. They capitalized on gender inequities to work in traditional "female" occupations as laundresses, cooks, and seamstresses but also moved into previously male-dominated industries such as barbering, where they took advantage of women's lower pay to dominate the industry. Some Issei women also had professional training in fields like midwifery and were respected and known throughout the plantations for their expertise and knowledge that helped sustain many communities. Finally, Issei women involuntarily 
and voluntarily engaged in prostitution, a lucrative profession for both the women and their pimps. In Hawai' i, women's economic success, as well as their exploitation, was directly tied to their femininity with their sexuality giving rise to new identities and roles in the community that challenged the stereotype of passive picture brides and silent, industrious field laborers.

\section{Laundresses, Cooks, and Seamstresses:}

\section{Domestic Industries on the Plantations}

While many women were employed directly in plantation production, others performed important support functions on the plantation, as they served the domestic needs of single men by washing laundry and cooking meals. Many of these jobs were necessary to supplement income from regular plantation work which did not cover basic living needs. According to scholar Evelyn Nakano Glenn, the work that Issei women performed shared distinct characteristics: it could be fitted around family responsibilities, involved tasks that were an extension of women's work in the home, and was in a low-technology, labor-intensive field where low wages and long work hours reduced competition from white women. Further, it often took place in a family-owned or ethnic enterprise where language barriers and racial discrimination did not constitute barriers to employment. ${ }^{16}$ These factors explain why Issei women often washed men's clothes or cooked or sewed for extra income in addition to their regular work on the plantations.

Laundry in particular was considered to be women's work. Many women, like Motoe Nihei, often did laundry on the weekend and were assisted by their children, who picked up laundry from the Japanese and Filipino bachelors in the community. As Nihei remembers, "My children used to go [pick up laundry]. They know the Filipinos' name ... They go gather the bachelors [laundry] on Friday afternoon and bring "em up. Saturday, after work, I used to." ${ }^{17}$ Filipino workers solicited Kame Iwatani to wash their clothes for them. She recalled that when the workers asked her, "Won't you do laundry?" Iwatani, who had limited language skills, simply responded with, "Oruraitto [i.e., All right]." ${ }^{18}$ Without any helpers, Iwatani instructed the Filipino workers to bring her their clothing to be washed at a designated time 
each week and return a week later to exchange their dirty clothes for their freshly washed and pressed garments.

For many women, laundry was a labor-intensive activity that often took a number of days. "Washing clothes was a whole day job on Sundays," remembers Mine Sekine Omiya. "What we did was build a fire outside under a 5 -gallon kerosene can filled with soapy water. We would boil the dirty clothes . . the brown soap was really strong those days ... then take the clothes out and beat them to get the dirt out. I used to hang out clothes out for several days because it took so long to dry." ${ }^{19}$ Nihei also recalled that the dirt and sweat embedded in the garments required considerable effort to remove. Nihei used to "boil 'em, put 'em in the big tub with lots of detergent inside. Boil 'em, and then we take 'em out just like [how the ladies in Korea used to do]. We used to pound it, pound it [with a stick], and rinse 'em in the water. Used to be real nice and clean." ${ }^{20}$

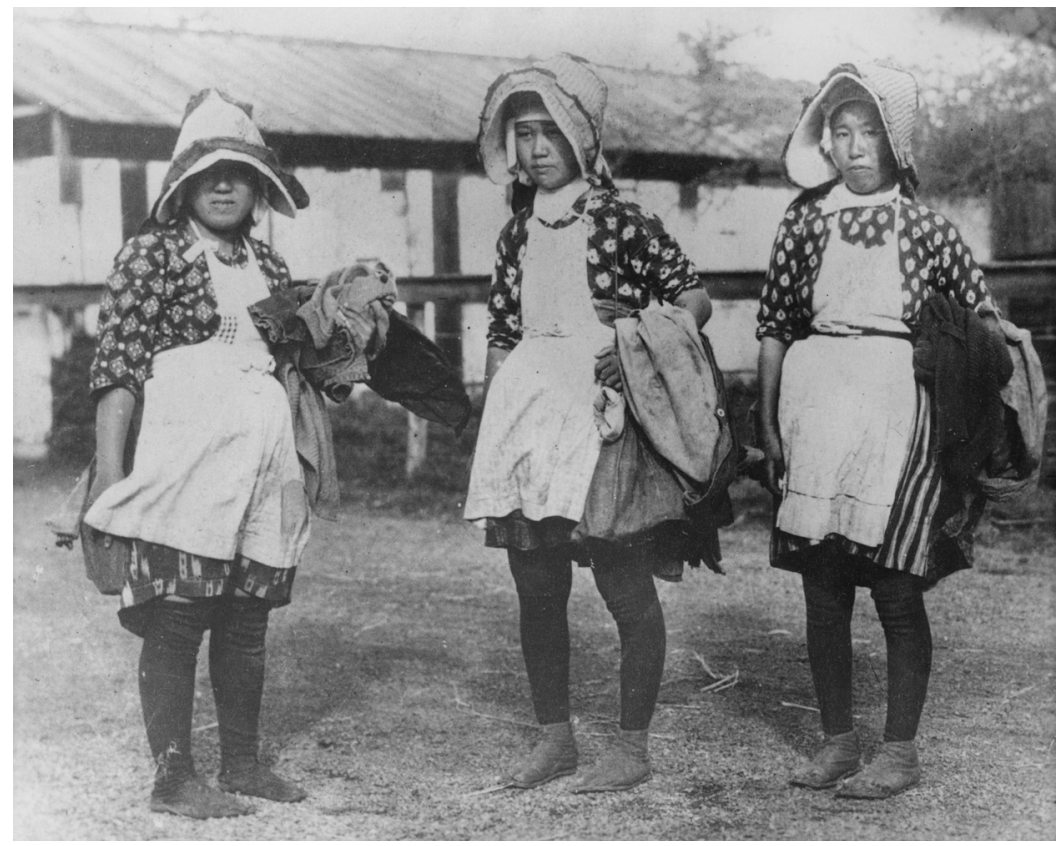

Figure 1. Japanese women sugar plantation field workers, ca. 19oo, Courtesy Hawai ‘ 1 State Archives. 
After washing and drying the clothing, women then had to iron the garments. For Iwatani, ironing took another two to three days to complete. As Iwatani explains, "If there was electricity, it [work] would have been good. But in the old days, it was charcoal. Charcoal-sumi. That you heat up and iron." ${ }^{21}$ According to Iwatani, "In the old days, I had to heat up the coals, fan it with a fan, heat up the coals, and then with that, do the ironing. The people of old really suffered. Now, it's really a wealthy man's life." ${ }^{22}$ For their efforts, Iwatani and other women received approximately $\$ 2$ to $\$ 5$ a month per person for laundering and ironing clothes during a time when the average male contract worker could expect to earn $\$ 15$ a month.

Besides laundry services, many women were also solicited to cook for the men on the plantations and had to learn how to plan and budget for meals that needed to keep the entire day without refrigeration. Iwatani, who washed and cooked for the men, explained this dilemma: "It was every day, every day, every day . . . so it was difficult. What should I make today? What should I make tomorrow? What foods should I make tonight?" ${ }^{23}$ Iwatani put great consideration into her menus as she thought, "It is not good to serve the same things every day, right?" Two to three times a week, vegetable and fish sellers, as well as representatives from local stores, visited Iwatani for her weekly purchases. In planning her menu for the week, Iwatani needed to first calculate the number of men and cost of the food, weighing the need to economize with customer satisfaction:

Because there was a certain number of people, a certain amount of supplies had to be purchased. Even fish. For example, fish ... we had to arrange to give a pound of fish for three people. Otherwise I couldn't calculate [how much was needed]. There were 15 people; I had to buy a certain amount ... Profit? If you feed them a lot of delicious food, you lose, right? But if you don't feed them [good food] I'd be complained to. So, I really have to economize to feed them..$^{24}$

Breakfast and lunch often consisted of traditional Japanese fare made from products obtained locally. For breakfast, women sometimes prepared miso soup, flavored the stock with iriko (small dried sardines), and added pumpkin or sweet potatoes to the soup. For lunch, women would pack bentō (boxed lunches) consisting primarily of rice with pieces of vegetables such as radishes, cabbage, cucumbers, mustard 


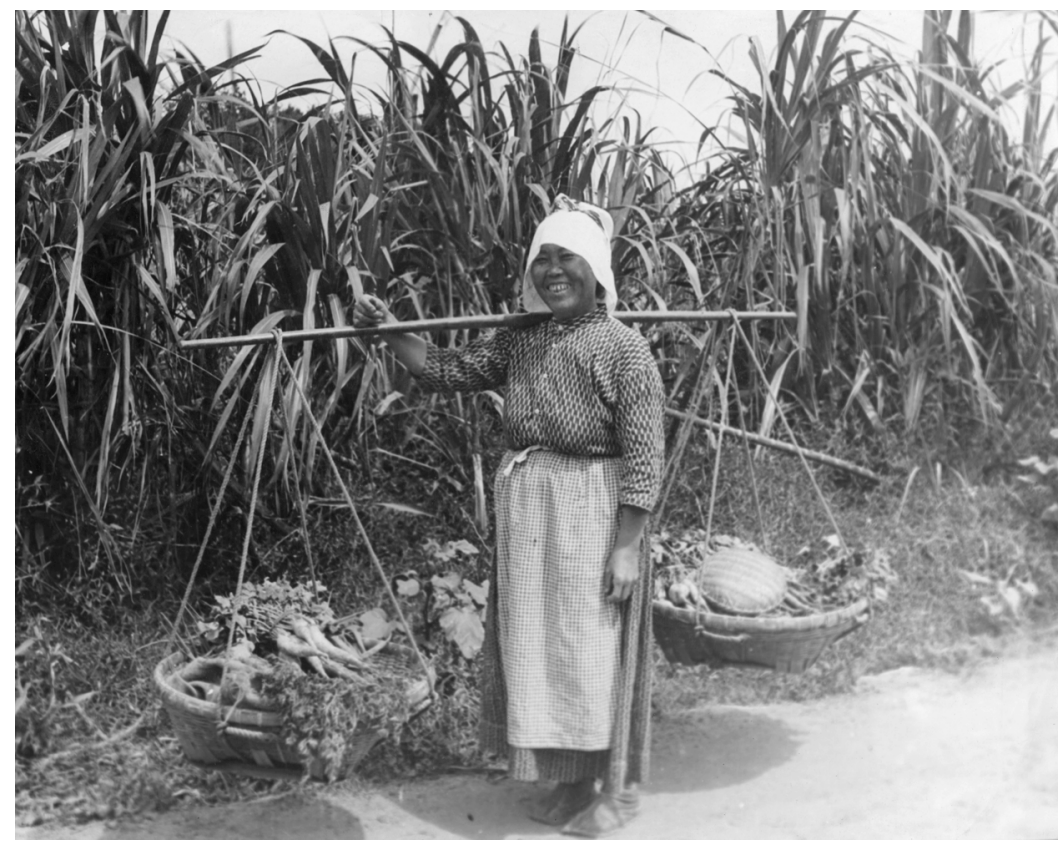

Figure 2. Japanese woman farmer offering vegetables for sale. Waimanalo, $\mathrm{O}^{\prime} \mathrm{ahu}$, ca. 1925. Photographer Ray Jerome Baker. Courtesy Hawai'i State Archives.

greens, or scallions. ${ }^{25}$ They also added dried, salted, or fried fish when available.

Taga Toki, who was unexpectedly given the responsibility of making bentō for twenty bachelors when her husband was working on a tunnel project in Kōke'e, Kaua'i, in the 1920s, described the challenges of making bentō for hungry workers each day:

I got up at 3:0o A.M. . . . My second baby often woke up and cried, so I strapped him to my back to do the cooking. The rice was cooked in a large Chinese pot with a heavy lid, on an open fire outdoors, so it was very good. Every morning, I lined up the double decker bento canstwenty of them-and filled them with rice, and a piece of fish, and pickles. Then the workers filled their own tea bottles and packed their bento cans in the ahina [denim cloth] bags. Once I bought a lot of fish cheap, and I fried it the night before and put some in each of the lunch cans. One man complained that he did not have any fish in his lunch 
can; the fish was so tasty that someone had taken it ... So, at times like that, I was in a dilemma and did not know what to do? These incidents did occur occasionally even among the Japanese laborers when food was especially good and a rare treat. ${ }^{26}$

To ensure that workers were fed and given their lunches before heading out to the fields, women like Toki needed to wake up extra early and prepare the morning and lunchtime meals. If they had children, they often left the younger ones in care of an older sibling or with their husbands or strapped infants to their bodies as they worked in outdoor or communal kitchens.

\section{"EVEN NOW I CAN HEAR HER WAILING": \\ Childcare AND WOrk ${ }^{27}$}

Many women like Toki and Iwatani had numerous side businesses that required them to work from early in the morning to late at night in between raising children and maintaining their own households. While women were employed outside the home, they were generally also responsible for the customary "women's work" for the family, and in addition to income-earning work, migrant women cared for their large famililes without female kin support, which they would have expected in their home villages. Although in Japan, a woman's workday lasted from before dawn to after nightfall, they could at least expect assistance from other family members-older children or the mother- and father-in-law-to care for the children. ${ }^{28}$ In Hawai'i, however, the lack of an extended family network resulted in women leaving young children in the care of older siblings or at home alone while others worked the night shift. Other women like Osame Manago also had no choice but to neglect their children while they were working:

The baby was growing, and he started to crawl. I used to tie him to two places outside with my obi [sash], and go to pick up horse kūkae, dung. And people could hear my baby cry. My husband would come to tell me that the baby was crying .... When I went back to the baby, he had cried himself to sleep, and his diaper was soaked. I felt so sorry for him. ${ }^{29}$

Women also took their children with them when they worked and an untold number of children died or were injured in workplace acci- 


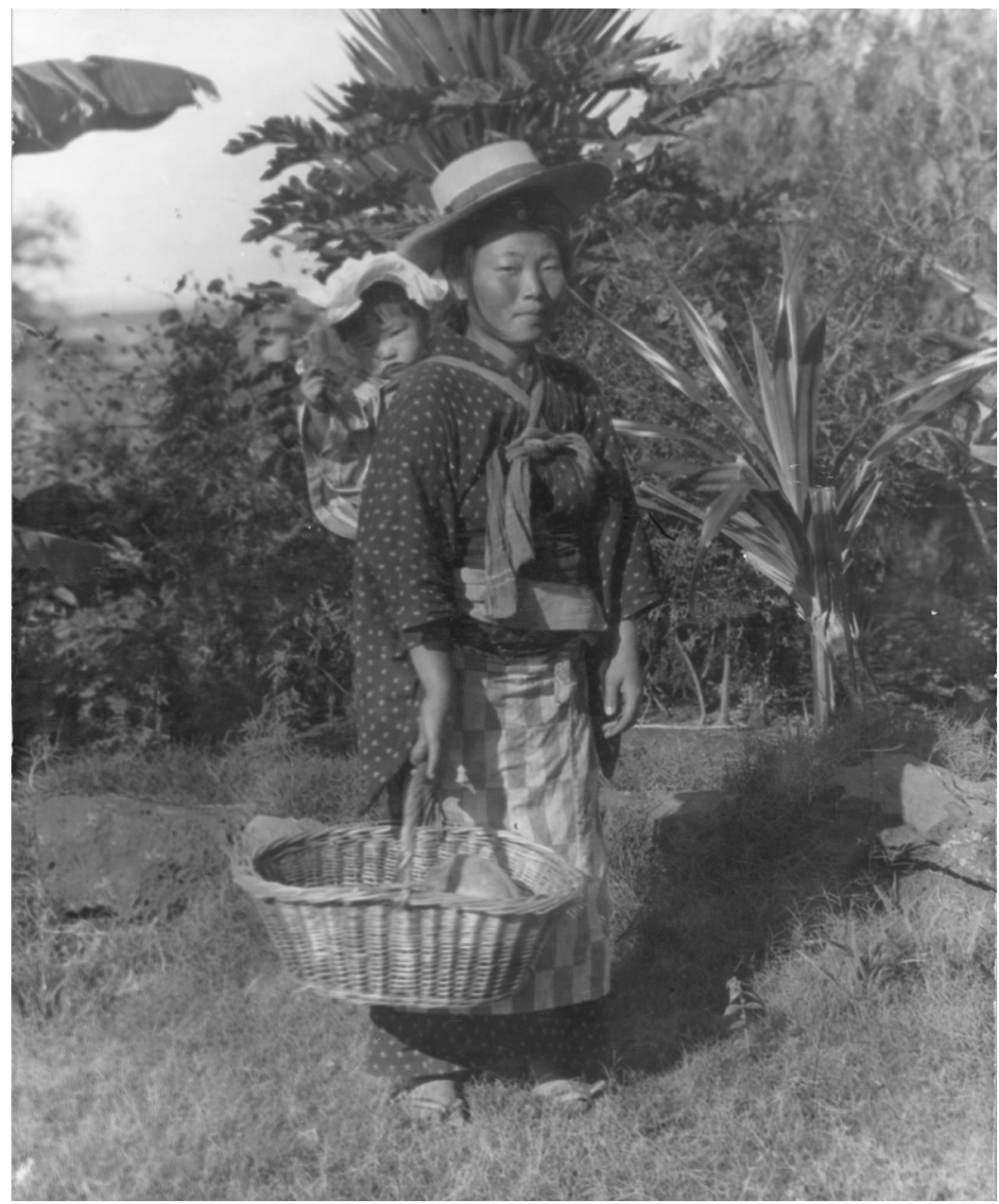

Figure 3. Japanese woman with Child, Pu'unēnē, Maui. Undated. Photographer Ray Jerome Baker. Courtesy Hawai'i State Archives.

dents. ${ }^{30}$ Issei women often worked until the day of their delivery, took their babies to work, and left infants under makeshift shelters in the fields to shield them from the sun and from biting insects. A hole hole bushi [plantation work song] captures a mother's lament as she faces overwhelming circumstances: 
It's starting to pour

There goes my laundry

My baby is crying

And the rice just burned. ${ }^{31}$

Many women faced a "double day": after finishing a full day at work, they started a second shift of domestic labor at home necessitating long work hours and very little sleep. ${ }^{32}$ Shinyu Gima recalled, "For fifteen years, I made tofu [soybean curd]. Every morning I got up at two o'clock to start making it." 33 Gima also raised hogs, washed clothes for the single men in the camp, and taught dressmaking to young girls. Issei women like Gima who possessed sewing skills, not only taught sewing to other women, but also were in high demand to sew plantation garments like $k a p p a$-raincoats made of strong cotton which, after being soaked with linseed oil, were waterproof. "We made sure we didn't go near a fire wearing those raincoats, no matter how cold it was. We heard of one kappa that caught on fire," remembers one Issei woman. ${ }^{34}$ They would also make straw slippers and sell them at a cheaper price than at the plantation store. "We would unravel fertilizer bags and weave them into a lightweight pair of slippers. They

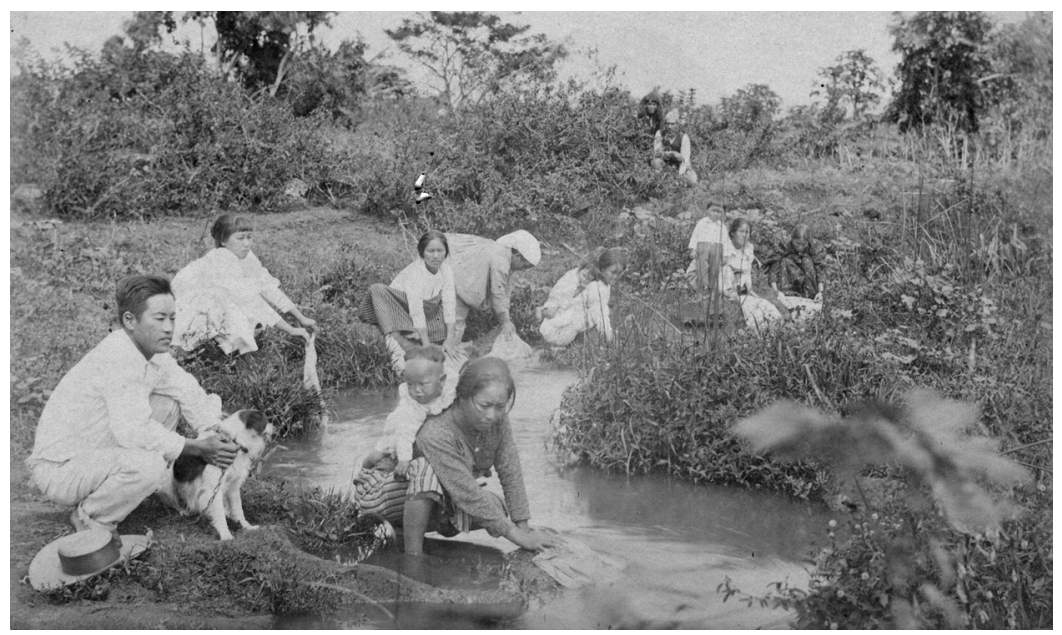

Figure 4. Japanese women washing clothes while caring for their children. Undated. Courtesy Hawai'i State Archives. 
were just right for home use," recalled Mine Sekine Omiya. Women were indispensable for sewing clothing on the plantations, adapting fashions from Japan and other ethnic groups to suit their needs. ${ }^{35}$

The domestic skills of certain women were recognized not only by their families and other laborers who purchased their clothing but also by white plantation owners who hired these women as laundresses and seamstresses. The wife of a luna hired Osame Manago as she was sympathetic that Manago had to neglect her infant while she conducted her job of picking up horse dung in a large field every day. To ensure that Manago could more readily care for her children, the woman gave some pieces of cloth to Manago to embroider after teaching her how to sew. As Manago recalls, "When I had finished a few napkins and handkerchiefs, my husband took them to her. He told her he wasn't sure if the work was satisfactory, but if it was, I would be glad to do some more. Pretty soon I was doing big table clothes for those English people." ${ }^{36}$ For her efforts, Manago was given ten to fifteen dollars depending on the type of work she completed, equivalent to a month's wages.

\section{"Wife Selling": Japanese Prostitution in Hawai'i 37}

In lieu of long work hours and little pay in industries like laundry services, cooking, and sewing, women also voluntarily and involuntarily engaged in prostitution, often at the urging of their husbands. ${ }^{38}$ According to historical accounts, a Mrs. Nakamura who arrived with the first group of Japanese immigrants or Gannenmono in 1868 was the first Japanese prostitute in Hawai' $i .{ }^{39}$ Twenty-four years later, after larger numbers of Japanese had begun to arrive, Edward G. Hitchcock, the sheriff on the island of Hawai'i wrote, "I wish to call your attention to the fact, more or less prevalent on this island, of these Japanese selling their wives or mistresses to each other." ${ }^{40}$ Officials on the other islands also expressed their concerns of Japanese prostitution, such as the sheriff of the island of Maui who wrote a letter about his concerns regarding Japanese prostitution:

In connection with Japanese the custom they have of trafficking in their women, buying and selling their wives is an evil that should be looked into, and if there is a remedy, it seems to me it should be earnestly 
sought and applied with a vigor, that would make the practices of this nature, which are demoralizing and an outrage in a civilized community, impossible. Again there is little doubt that this is a fruitful source and to which cause might often be traced to the motive of the most violent crimes that have been committed by Japanese on our Island. In support of this we have the case of Sagata, the wife and child murderer, who was actuated to commit a crime the most revolting of which we have any record, because he had only received only-half the price for his wife that had been agreed upon. ${ }^{41}$

The sheriff reiterated these sentiments in his report of 1904 and urged a law to end wife selling. ${ }^{42}$ According to historian James Okahata, the practice of "wife selling" began when chief inspector Jōji Nakayama collected $\$ 5$ o from men who had arrived in Hawai 'i with wives, but were returning to Japan alone. Fearing that wives were left behind without passage, Nakayama collected funds to ensure that the wives' passage would be taken care of when they desired to return to Japan. However, wives sometimes left their husbands for other men. Subsequently, the husband would attempt to collect the $\$ 5^{\circ}$ he had deposited with immigration officials from his former wife's new partner. Eventually, the "price" of a wife dramatically increased to nearly $\$ 15$ oo in some instances when "unscrupulous elements" started to arrive from Japan and men sold women to houses of prostitution. ${ }^{43}$

Some husbands coerced their wives into prostitution under the threat of violence. For example, in the divorce filings of Mizi and Sentaro Iwamoto, Iwamoto allegedly "illtreated and cruelly assaulted and beat," his wife to force her to "consent to a sale of her body to a third party." 44 Upon her refusal, Iwamoto visited his wife at her place of employment and "made an attack upon her with a knife, putting her in great fear and danger of bodily harm." On October 7, 1907, Tsuya Ogawa filed divorce proceedings against her husband, Namahichi Ogawa, for using "extreme cruelty" to "force Libellant [Tsuya Ogawa] to go to Iwilei to lead a life of prostitution." When she refused, he beat her on three separate occasions throughout the month of November, causing "extreme pain an[d] suffering." 45 In response, Ogawa took legal action to emancipate herself from her husband.

Among the 3,726 Japanese women who arrived in Hawai'i by 1900 there were likely some prostitutes as women were in demand in a 
predominately male bachelor community. ${ }^{46}$ Throughout the early immigration period, the majority of arrivals from Japan were men, as many had hoped to earn enough money to return home wealthy. Yet, dreams of wealth soon faded in the harsh working conditions on the plantations and as many began to realize that Hawai' $i$ would become their home, they desired to start families. As it was difficult for unmarried women to migrate to Hawai 'i, many came or were sent to Hawai' $i$ as picture brides as part of the period of "summoning families" or yobiyosei jidai. They were entered in their future husband's family registry in Japan and but upon arriving in Hawai' $i$, but they became prostitutes rather than wives.

Pimps used promises of marriage and economic opportunity to lure gullible young women from their families and hometowns and later forced these women into prostitution. In a report written by the Committee on Social Evil in May 1914, the authors reported that some prostitutes were "brought into the Territory as picture brides as men who desire to exploit them for their own gain." ${ }^{47}$ Of the 107 prostitutes surveyed at Iwilei, 82 were Japanese, 14 were Puerto Rican, 6 were French, and 5 were American. As picture brides often travelled alone to an unfamiliar environment with limited knowledge of English, they were particularly vulnerable to exploitation. Thus, in Hawai'i, many Japanese prostitutes were married, which was unusual in Japan. ${ }^{48}$ More commonly, however, prostitutes were single women. The 1896 census reported 838 unmarried Japanese women out of 4,064 or 20.63 percent of Japanese women fifteen years and older. The superintendent of the census wrote, "It is safe to say that a considerable number of these are leading an immoral life." ${ }^{49}$ Some prostitutes worked on the plantations, a fact alluded to in Milton Murayama's All I Asking For Is My Body, when the main character Kiyoshi, does not realize that his friend Makoto's mother is the resident prostitute for the Filipino laborers. As Makoto's family is the only Japanese family living in the Filipino camp, they are shunned by the rest of the Japanese laborers.

Prostitution also flourished in urban areas, particularly in ethnic neighborhoods. The majority of women sold or attracted into prostitution were controlled by Japanese gangsters, especially in Chinatown in Honolulu, where women were organized into groups called Hinode (Rising Sun), Gikyo (Chivalry), and Isshin (Whole-hearted, One Mind) 
to control and regulate the growing prostitution business in Hawai' $i$. In 1896 , the Honolulu Advertiser noted that there were a "hundred odd women" engaged in prostitution along Nu'uanu Street and described the area as a "hotbed of [v] ice and immorality." ${ }^{50}$ In 19oo, a number of Honolulu churches launched an unsuccessful campaign against "the degenerate class of Japanese men who live off the earnings of fallen women of their race" when the Hawai'i Supreme Court ruled that these men could not be held on charges of "disorderly conduct" for promoting prostitution. ${ }^{51}$

Despite efforts to end prostitution, it was a lucrative profession for both the pimps and women as prostitutes could make at least $5^{\mathrm{O} \not}$ to $\$ 1$ per customer and attractive women could earn nearly \$20 per night. While male plantation workers earned an average of $\$ 15$ per month and salaried workers \$18 per month, prostitutes could earn about $\$ 200$ at the end of the month to send to their families back home in Japan. ${ }^{52}$ The prostitutes who worked in both Chinatown and Iwilei clearly recognized the economic advantages of prostitution. The Reverend Takie Okumura, a Japanese Christian minister in Honolulu, was patrolling the streets of Honolulu when he came across a Japanese prostitute. In his memoirs he recorded his encounter with this woman:

One day I visited the home of one harlot, and urged her to return to clean, decent life and work. She said: 'Doesn't a big, healthy man on the sugar plantation get only $\$ 14$ a month? I'm far better off, for in this work I can save up and send back \$200 a month to my home in Japan. Am I not the real patriot who enriches our country?' ${ }^{53}$

While this prostitute put forth a very rational argument, Okumura spent great effort attempting to reform the approximately 200 prostitutes and 3 oo pimps in Honolulu. Attorney General Henry E. Cooper noted that the prostitutes were controlled by Japanese men, often their husbands.

Although men undoubtedly oppressed and exploited many women who were forced into prostitution, some women did freely engage in sex for payment in lieu of hard labor on the plantations. A hole-hole bushi song captures the reasoning of such women: "If I work at stripping hole-hole bushi, all I'll earn is $35^{\not}$. If I sleep with a Chinaman, I'll make $\$ 1$.oo." ${ }^{54}$ For some women, prostitution was a more 
attractive option than the backbreaking labor of field work or the long hours involved in domestic industries. For others, however, life in Hawai'i also offered opportunities for professional advancement, such as midwifery, based upon their particular qualities as women helping other women.

\section{HAWAi'i SANBA (JAPANESE MidWIVES)}

Historically, the experience of sanba [Japanese migrant midwives] has been overshadowed by the role of Japanese doctors in the fledgling Japanese community. Scholar Susan L. Smith explains the historical invisibility of Issei midwives as a "result of initial government indifference to Japanese women's health needs, as well as gender inequality within the migrant community and among health-care professionals." 55 Thus, neither Japanese nor Hawaiian government officials made efforts to bring over midwives to care for female plantation workers. Additionally, midwives lacked prestige because most worked at homes rather than in hospitals, which were increasingly seen as professional settings and centers of modern science. While some midwives worked in private Japanese or plantation hospitals, midwifery remained a primarily home-based profession, as doctors themselves transitioned from attending patients in the home to caring for them in offices and hospitals.

Despite midwifery's lower status in the healthcare hierarchy, sanba were important to their clients, families, and communities. In the Islands, cultural traditions, sexual propriety, and economic considerations led most Japanese as well as other migrant women to choose midwife deliveries over attendance by Japanese or white doctors. As Issei midwife Misao Tanji of rural O'ahu explained, before World War II, "most women preferred to be under the care of a midwife, unless there was some complication with the mother's or fetus' condition." "56 Tanji's observations of women's preferences for a midwife and home birth were shared by others, including Faustino Baysa, an employee at the Waialua Sugar Company. According to Baysa, most women gave birth at home and were assisted by midwives. As Baysa recalled, "There was a Mrs. Toyo Yamao who used to be very popular. And Japanese and Filipinos used to call her whenever the thing happened." ${ }_{57}$ The only times doctors would be called, Baysa remem- 
bers, was "when they have unusual cases like breach or things like edema." Otherwise, many women relied on the services of midwives like Tanji, who arrived in the Islands with professional degrees and credentials, fulfilling a critical need on the plantations to help stabilize the migrant community.

Misao Tanji arrived in Hawai'i after marrying Takeo Tanji, a Christian Japanese migrant who had returned to Japan in search of a wife for himself and, at the request of a minister, a midwife for his community. Tanji was born in Japan and graduated from a nursing and midwifery school in Tokyo in 1921 . She passed the midwifery requirements at the national and prefectural level in Japan and apprenticed for one year with an experienced midwife. According to Tanji, she studied midwifery because she thought she was not attractive enough to marry and needed a way to support herself. When an arranged marriage was proposed with Takeo Tanji, she immediately accepted. Although it was not "love at first sight," Tanji was "happy because I didn't think any man would have a homely girl like me for a wife." 58 She and Takeo married in Japan in 1923 and in 1924 sailed to O'ahu. "I had high expectations and hopes for the future," recalled Tanji. Upon her arrival, she was delighted to learn that Hawai'i was indeed the paradise she had heard about. According to Tanji, "The trip from the immigration station to Wahiawa was so beautiful. The vegetation was lush; the mountains were bright and green. Even now I have that picture etched in my mind." 59

While many women engaged in backbreaking physical labor on the plantations, Tanji capitalized on her training and expertise in midwifery to enjoy a professional career. In Hawai'i, Tanji became a successful entrepreneur who benefitted from not just her education, but her husband's support of her job. Unlike most Issei who worked and lived as laborers, the Tanjis lived in Waipahu at the back of Takeo's photography studio, where they raised a family of two sons and one daughter. While Tanji attended to her clients, her husband looked after the household, cooking, cleaning, and tending to the children in a reversal of traditional gender roles. Tanji took great enjoyment in her profession, recalling that "work was my recreation," and noted that she was "very fortunate" to marry her husband, who "used to help in all the household chores so I was free to pursue my interests." 60 Tanji's professional career also benefitted from the fact that because 
of her husband's business, she had access to a telephone and eventually obtained her driver's license to attend to clients instead of being driven by the taxi driver, Mr. Noguchi, who owned a Model T.

Over the course of her career, which spanned more than 30 years, Tanji delivered babies not only as a way to make a living, but also to help women, many of whom could not afford her services. She provided prenatal, delivery, and postnatal care for about $\$ 10$ to $\$ 15$ at the beginning of her career and $\$ 35$ and $\$ 5^{\circ}$ after World War II. Although there was a set fee for her services, clients sometimes paid her with fruits or vegetables raised in home gardens or even nothing at all because plantation families had so little. Paying for services with foodstuffs was evidently common practice for the clients of midwives. Thomas Lee, the public affairs coordinator of the Waialua Sugar Company, remembers paying a Japanese midwife "three dollars and a couple of chickens" for assisting his mother during his brother's birth. ${ }^{61}$

Due to the low economic status of their clients, many sanba, including unlicensed midwives on the plantations, could not expect full payment for their services and often charged little or nothing to deliver babies. To support their own families, many of them also performed agricultural labor, worked as domestic servants, sold flowers, or were employed in a family-run general merchandise store. Tsuru Yamauchi, a migrant from Okinawa, remembered that the midwife for her first baby was also a plantation worker who lived in another camp:

In those days a midwife just helped a baby be delivered, come out, you know. She took care of the umbilical cord and cleaned the rest. She bathed the baby and things like that. She would come back the next day to bathe the baby again. But it was far away, so as soon as the umbilical cord fell off, she stopped coming. ${ }^{62}$

Unlike doctors who simply practiced medicine, many midwives had multiple responsibilities and needed to balance midwifery with other jobs they held. But they too faced increased pressure for the regulation of their profession under the Territorial government.

By 1931, there were forty-eight registered midwives in Hawai' $i$ as required by legislative decree-all of them Japanese. ${ }^{63}$ Many of these midwives served not only Japanese clients, but also women of different ethnicities on the plantations including Chinese, Filipino, 
Korean, Portuguese, and Hawaiian women who fondly remembered these Issei women. According to Antone Camacho, a retired field supervisor, his daughter was delivered by a "Japanee woman, Inouye" who Camacho claimed was "just as good as a doctor" after both his daughter and wife survived a difficult childbirth. ${ }^{64}$ In communicating with the midwife to assist his wife, Camacho recalled that they used a mix of Pidgin English and gestures:

She tell me, 'Bumbye, me speak chikara' (and make a tight fist to signal you so you can signal your wife). And I say (to my wife) 'If I say make strong, make. If I no say nothing, then (the midwife) rub the stomach, see.' And then, you see, this time pau. No more pains again eh. (The midwife) touch again (and said) 'This time come,' then, pain come back again. Three or four times she went like that. 'Ah, this time. Antone, you speak (to your wife). You speak chikara. You speak.' So, I was sitting close by her. She tell me if I had the hot water on. I said 'Yeah.' Oh, (the midwife) right there. After a little while, the baby was born. ${ }^{65}$

With cross-language communication, these women were able to serve an extensive and diverse clientele of the wives of workers or the workers themselves and were welcomed in the various camps that separated workers by ethnicity. Upon her arrival, Tanji recalled that there were five other midwives, including a "Mrs. Ishikawa" and "Mrs. Koike," whose Japanese clientele exclusively patronized because of a feeling of reigi [courtesy] to their original midwife. As the last one who "muscled in," Tanji appreciated her clients of different ethnicities as "the relationship with these people was easier than with the Japanese, because with the latter there was constantly a feeling of mutual reticence," unlike other women, who were "very candid." 66 Despite her own limited language skills, Tanji had no problem communicating with her clients and their families as in her job "communication is by gestures," and she did not need fluent English skills.

Besides offering prenatal and postnatal care, these women maintained birth records for entire plantations and communities and became repositories of community knowledge. Camacho recalled that the Japanese midwife on the plantation "had a record, you know, that son of a gun lady." According to Camacho, "Every baby was born with her, by her she had all that record. Not like how some of them, 


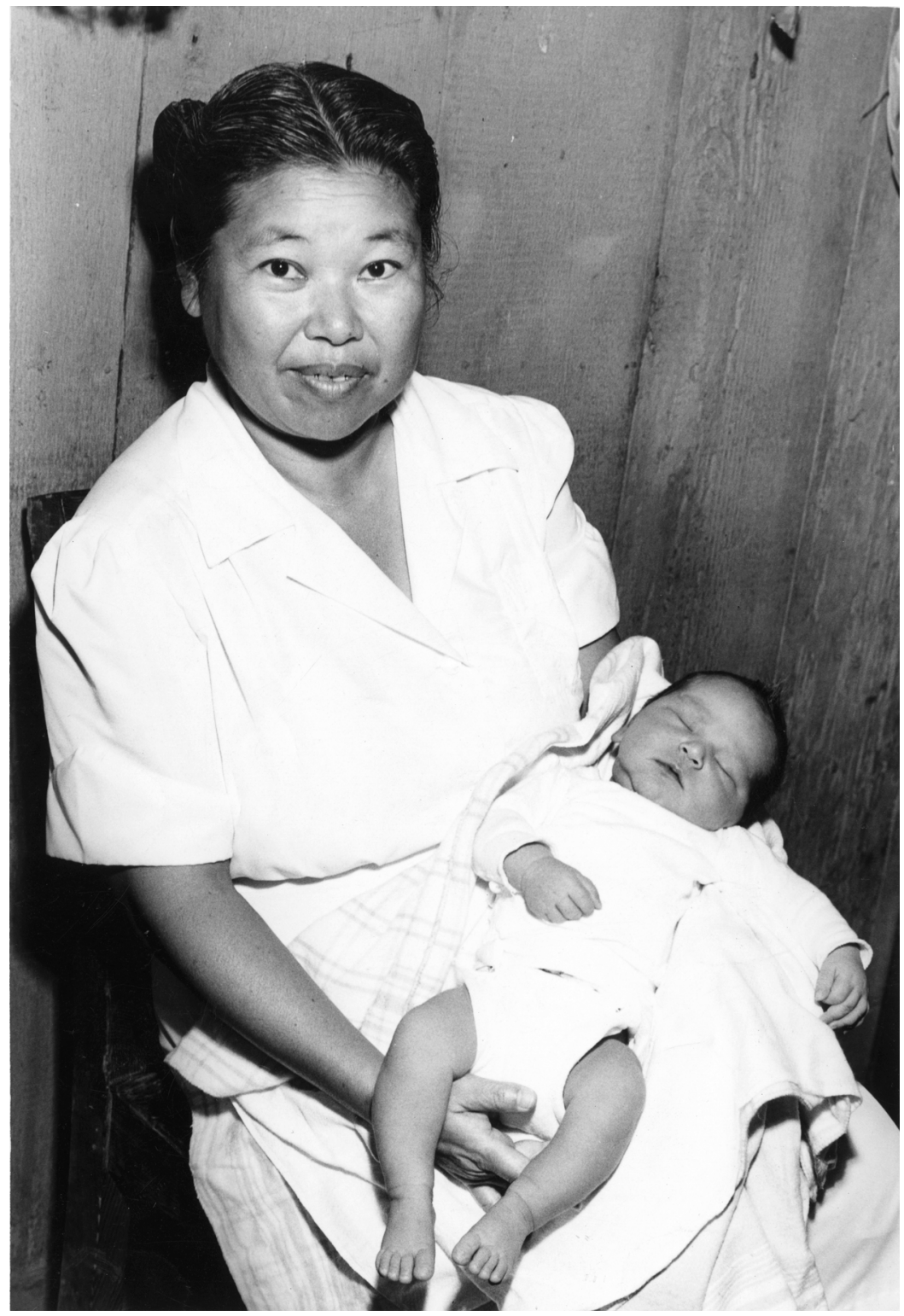

Figure 5. Midwife Elsie Masao Tsuchiyama holding a baby. Honolulu, ca. 1950. Courtesy of Bernice Pauahi Bishop Museum. 
they no more record, nothing. They don't know how many babies was born. No, this lady had all in a book. So and so was born certain day." ${ }^{67}$ When birth certificates were needed by workers, families relied upon the records kept by midwives for documentation.

Midwives were valued members of the community, and men and women of all different levels of the plantation economy regarded them with great respect and remembered them with fondness. On the Waialua Sugar Plantation, Baysa recalled that "there was a Mrs. Kito Sasaki. And there was a Mrs. Kane Mukai who used to do. You know, this Sagara's mother. Mrs. Sagara's mother was a midwife. She used to come in." ${ }^{68}$ According to Baysa, when these women came in to register as midwives, they sought his assistance, which he was more than happy to provide. Baysa, who became a "good friend" to many of the sanba, stated, "That's why I say I always thought that I was lucky because I was there. Whenever they needed help, I could help them.” For Baysa, by assisting the sanba, he could express his gratitude for the services they provided to the families in Waialua. Although many sanba did not enjoy the professional accolades that were given to male physi-

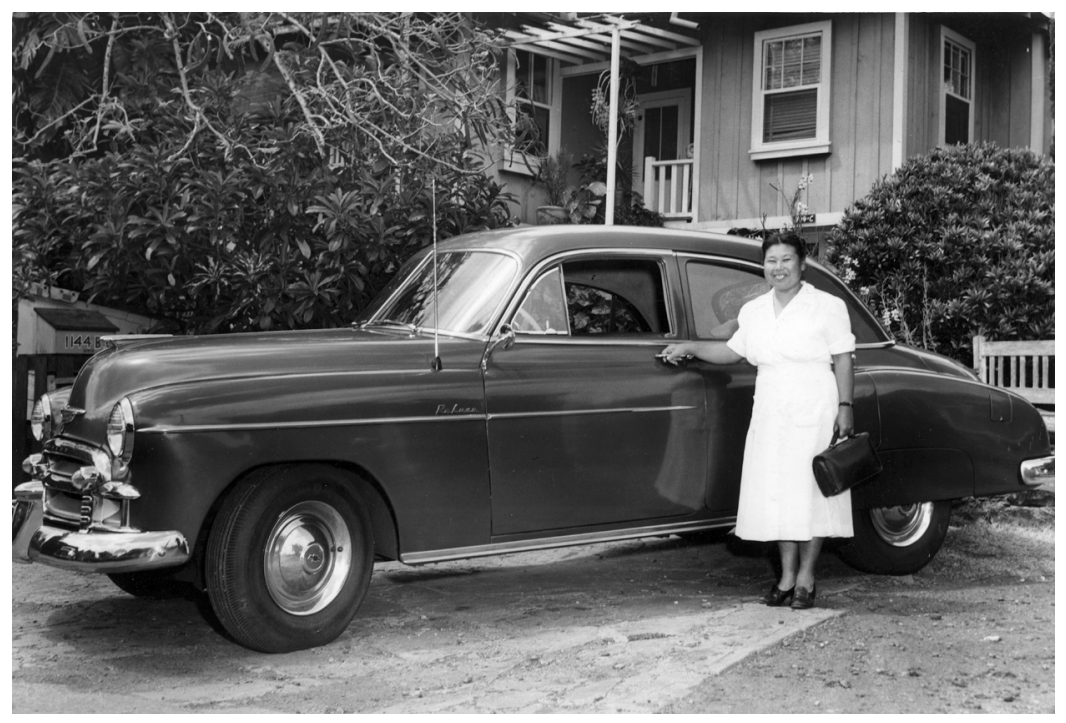

Figure 6. Midwife Elsie Masao Tsuchiyama with her $195^{\circ}$ Chevrolet. Honolulu, ca. 1950. Courtesy of Bernice Pauahi Bishop Museum. 
cians, their status on the plantations and in the Japanese community was not tied to their financial status. For instance, when midwife Uto Nakamatsu died, the adult children of the women she had attended in childbirth came to her funeral from all over the Islands. Tanji herself recalled that because she used to assist a family who worked in Kipapa, even after World War II, her client continued to supply her with vegetables in appreciation for the times that they could only pay Tanji for her services in vegetables raised in their home garden. ${ }^{69}$

\section{“The Little Brown Lady Who Cuts Hair": Honolulu Barber Girls ${ }^{70}$}

Issei women also dominated certain industries like barbering, where in lieu of a formal academic education, they could apprentice and receive on-the-job training. Women often assisted and in many instances joined their husbands in their chosen professions, as was the case with the barbershop trade. According to scholar Yukiko Kimura, as Japanese men entered the commercial life of the cities, the wives of men who owned barbershops began helping their husbands until it became known as a "woman's trade." 71 As in other plantation industries, women took advantage of the fact that as they worked for lower wages, \$12.00 compared to $\$ 15$.oo for men, it became cheaper to hire and keep women. Denied educational opportunities, women could receive professional training at little or no expense, beginning as apprentices usually around the age of 14 to 16 , in shops owned by family or friends of their family. ${ }^{72}$ Many Issei and Nisei women shared the same experience as Edna Kondo, who began as an apprentice in her aunt's shop at the age of thirteen in 1939. As an apprentice, she explains, "I took care of babies, cleaned the shop, washed the towels and cooked. When I had spare time, I would have to stand by the barber's chair and watch how they cut. In the old days, you had to be a maid to be a barber." ${ }^{73}$ Kondo added that this apprenticeship lasted a year and a half for her and what she received as payment was used toward room and board. After the year and a half, she was paid \$10 a month.

For many barber girls, their experiences were both empowering and limiting. Like their counterparts on the plantations and in other family-owned businesses, they were expected to work long hours that 
left little time for personal leisure or enrichment. According to June Yano, who began working as a barber on Hawai' $i$ Island, she and other women were expected to work from early morning to late at night. Usually, she says, "I would start at six in the morning and end at 10 or 11 at night. But sometimes on Saturdays, I worked until two in the morning. It was that busy." According to Kimura, the average work day for barber girls was 14 hours a day. However, this schedule was shortened as a result of a labor ordinance in 1939 that set the earliest starting time at 7 a.m. and the latest ending time at 8 p.m. for weekdays and 9 p.m. on Saturdays. Many of the barber girls appreciated this new time restriction as "there is not only the mental and physical relief, but the extra hours in the evening make it possible for us to have recreation and amusement" as they no longer were bound to work such long hours. ${ }^{74}$

Although the girls were no longer allowed to work excessively long work days, the limited time given for lunch or dinner did not increase. Most did not have a scheduled lunch break-one that ranged from five minutes to one hour-and were expected to stop eating whenever a customer came into the establishment. The same situation held true for suppertime, which explains why many of the girls ate with their proprietors or brought lunches to work. According to Kimura, "Long hours of work with no definite time for meals is a carryover from Japan where small business, like the barber shop, is carried on primarily as a family affair-where there are not outside employees except for a few apprentices." ${ }^{75}$ Barber girls, and the family they worked for, ate whenever they could and worked as long as it was necessary to accommodate customers.

While many female barbers worked for family or friends, ensuring that to some extent they would have greater autonomy or protection from outside influences, they did not enjoy complete personal and economic freedom. Nearly half of the girls Kimura interviewed revealed that they turned over all their wages to their parents to allocate for their or for their family's future needs. As Kimura explains, "This practice is in conformity with the traditional Japanese idea that everything belongs to the family." 76 She added, "Where the patriarchal family pattern is still effective, the daughter accepts this as a natural duty the rendering of her entire earnings to the head of the family expecting only the return to her of a small portion for spend- 
ing money." This patriarchal system was reinforced by the fact that many of the girls lived with their employers, who were the source of not only income and vocational instruction but also discipline.

Although Kimura states that the long working hours and "early conditioning" and training of the girls in the barbering profession limited their exposure to American culture and created attitudes that were "decidedly Japanese," their entry into a profession previously dominated by men and exposure, no matter how limited, to a multiethnic clientele resulted in the emergence of a new professional identity that transformed the industry itself.

\section{Moving Out/Moving Up: Issei Dreams of Economic and Social Advancement}

Issei women worked not only to support their families by providing needed supplementary income, but in many cases were also motivated by specific long-term goals to help elevate the economic and social status of themselves and other family members. Besides sending money home to family in Japan, some women like Kaku Kumasaka of Waipahu "worked constantly" in hopes of saving enough money to return to Japan. ${ }^{77}$ Kumasaka recalled a conversation she had with her husband, who promised her that in ten years, they would be able to return to Japan. "As things turned out," Kumasaka explained, "ten years, not even twenty was enough ... it was practically impossible to save from those meager wages." ${ }^{78}$ Thus, she resolved to work as she "did not want [her] children to be like me." Yet, her desire for a better life for her children came at the expense of caring for them. Other workers incessantly ridiculed Kumasaka for prioritizing her work over her children:

By working so hard, I was laughed at. I would hear fellow workers saying, 'Look at Kumasaka-san. Work comes before her children, and she calls herself a mother!' Even then I kept working. Thinking back now, I feel really bad. If we had any intentions of remaining in Hawaii, I supposed I would have not done what I did. But our only desire was to return to Japan after earning enough. We were really mistaken. The younger child was too young to know, but the older one used to cry every day when I left them at the baby home. Even now I can hear her wailing. ${ }^{79}$ 
Kumasaka and her husband became so intent on returning to Japan that instead of purchasing a house in Hawai'i with the money that they saved, they deposited it into Japanese banks. After World War II, they found they had lost much of it due to the devaluation of Japan's currency. Regretfully she explains, "We were really mistaken. Look at us now. We don't have anything, and we are going to end our lives here." 80

While Kumasaka's feelings of disappointment and resignation reflect some Issei women's attitudes, others appreciated the greater opportunities found in Hawai'i. Many Issei women made great effort to not only advance their careers, but also dedicated their lives to saving money to send their children to school to receive the education that had been denied to them. Misao Tanji proudly recalls that with the money she and her husband received from selling their photography studio, they were able to send their children to MidPacific Institute, a private boarding school, and to purchase a house in Waipahu. "We were not rich," explained Tanji, "and we did not want to put on appearances. We managed the family frugally." ${ }^{81}$ Kame Iwatani was similarly proud that with her hard work, she was able to "send them [her children] to college as long as they could handle it [academically]." ${ }^{82}$ Many women echoed Iwatani's sentiment of feeling gratitude for coming to Hawai 'i with its "good climate" and opportunities for a better life that was not available in Japan, especially after World War II. With their extra income, women and their families were not only able to move out of the plantations, but also dream about better economic and social opportunities for their sons and daughters as American citizens. These women served as examples for their children of not only the discrimination and hardships endured by Japanese in the Islands, but also the willingness, drive, and determination to challenge formidable race, class, and gender barriers in both Hawai'i and Japan.

\section{Conclusion}

Women who arrived in Hawai' $i$ as picture brides came with the expectation of both personal and economic opportunities as wives and workers. Economic realities in both Japan and Hawai'i ensured that women's financial contributions were essential to the economic sur- 
vival of the family, and many Issei women could not simply confine themselves to a domestic "good wives and wise mothers" role. Rather, many women embraced their skills as domestic workers to extend their influence outside the family sphere and create economic opportunities outside of field labor. Undoubtedly, Issei women endured great sacrifices, such as long work hours and the lack of proper child care, but they still worked a "double day" to advance their independence in their new island home. While many women experienced exploitation within this male-dominated society, as some prostitutes may have attested, others found opportunities in traditional "women's work," such as laundering, cooking, and sewing, which enabled them to exert a public influence that was critically important to their families as well as the larger plantation society. Women embraced professional identities as midwives and barbers, two professions dominated by Japanese women, and even out-earned men as prostitutes, escaping laborious field work. Women were critical to the economic security of their families but also to the larger community as they provided key services in Hawai'i's developing economy. In the process, they developed a public identity that has been overshadowed by the stereotype of the passive picture bride and industrious but silent field laborer.

\section{Notes}

${ }^{1}$ Ethnic Studies Oral History Project, Women Workers in Hawaii's Pineapple Industry Volume II (Honolulu: University of Hawaii, Manoa, 1979) 874.

${ }^{2}$ Sharon L. Sievers, Flowers in the Salt: The Beginnings of Feminist Consciousness in Modern Japan (Stanford: Stanford University Press, 1985).

${ }^{3}$ Barbara F. Kawakami, Japanese Immigrant Clothing in Hawaii, I 885-I94 I (Honolulu: University of Hawaii Press, 1993) 12.

${ }^{4}$ During the most critical stages of Japanese economic development, the land tax was the major source of government revenue. Until the twentieth century, it accounted for over one-half of government revenue; at the time of World War I, for slightly over one-third. Throughout this period, the tax burden on agriculture was at least twice as high as in other sectors of the economy. Henry Rosovsky, Capital Formation in Japan I 868-1940 (New York: The Free Press of Glenco, 1961) 85 .

${ }^{5}$ Dennis M. Ogawa, Kodomo no tame ni: For the sake of the children, the Japanese American Experience in Hawaii (Honolulu: The University Press of Hawaii, 1978) 23.

${ }^{6}$ Women Workers in Hawaii's Pineapple Industry Volume II 839. 
${ }^{7}$ Alan Takeo Moriyama, "Imingaisha: Japanese Emigration Companies and Hawaii, 1894-1908," Ph.D. diss., University of California, Los Angeles 1982, 21.

${ }^{8}$ Susan B. Hanley and Kozo Yamamura, Economic and Demographic Change in Preindustrial Japan, 160o-I 868 (Princeton: Princeton University Press, 1977) 255.

${ }^{9}$ Yukiko Kimura, "Psychological Aspects of Japanese Immigration," Social Process of Hawaii, VI (July 1940): 13 .

${ }^{10}$ At that time the rate of exchange was eighty-five cents to one yen, and fifteen dollars a month, which was the amount promised to Japanese workers, was the equivalent to 17.65 yen a month. This was a large sum for the average Japanese farmer in 1885 , as a roof tile maker could only expect to make 7.8 yen per month, a carpenter 6.3 yen per month, and a day worker 4.8 yen per month. Moriyama, "Imingaisha" 49.

11 Women Workers in Hawaii's Pineapple Industry Volume II 839.

${ }^{12}$ Kawakami, Japanese Immigrant Clothing in Hawaii, I 885-I94 I 194.

${ }^{13}$ Ronald Takaki, Pau Hana: Plantation Life and Labor in Hawaii, I835-1920 (Honolulu: University of Hawaii Press, 1984) 78.

14 Women Workers in Hawaii's Pineapple Industry Volume II 866.

15 Women Workers in Hawaii's Pineapple Industry Volume II 858.

${ }^{16}$ Evelyn Nakano Glenn, Issei, Nisei, War Bride: Three Generations of Japanese American Women in Domestic Service (Philadelphia: Temple University Press, 1986) 75.

17 Women Workers in Hawaii's Pineapple Industry Volume I 65.

18 Women Workers in Hawaii's Pineapple Industry Volume II 86o.

${ }^{19}$ Patsy Sumie Saiki, Japanese Women in Hawaii: The First Ioo Years, I835-I920 (Honolulu: University of Hawaii Press, 1984) 68.

20 Women Workers in Hawaii's Pineapple Industry Volume I 65.

21 Women Workers in Hawaii's Pineapple Industry Volume II 86o.

22 Women Workers in Hawaii's Pineapple Industry Volume II 860.

23 Women Workers in Hawaii's Pineapple Industry Volume II 876.

${ }^{24}$ Women Workers in Hawaii's Pineapple Industry Volume II 876.

${ }^{25}$ Kawakami, Japanese Immigrant Clothing in Hawaii, I 885-I94I 129.

${ }^{26}$ Kawakami, Japanese Immigrant Clothing in Hawaii, I 885-I94 I 129.

${ }^{27}$ Charlotte H. Tanji, Eight Life Stories: Japanese Senior Citizens of Waipahu (USA: Charlotte H. Tanji, 1984) 43 .

${ }^{28}$ Kathleen S. Uno, "Women and Changes in the Household Division of Labor," in Recreating Japanese Women, I60o-1945 (Los Angeles: University of California Press, 1991) 27.

${ }^{29}$ Hanahana: An Oral History Anthology of Hawaii's Working People, ed. Michi Kodama-Nishimoto, Warren S. Nishimoto, Cynthia A. Oshiro (Honolulu: Ethnic Studies Oral History Project, University of Hawaii at Manoa, 1984) 157.

${ }^{30}$ Donna Gabaccia, ed., Seeking Common Ground: Multidisciplinary Studies of Immigrant Women in the United States (New York: Greenwood Press, 1992) 130-131.

${ }^{31}$ Gary Y. Okihiro Cane Fires; The Anti-Japanese Movement in Hawaii, I865-1945 (Philadelphia: Temple University Press, 1991) 32.

32 Evelyn Nakano Glenn, “Cleaning Up/Kept Down: A Historical Perspective on 
Racial Inequality in 'Women's Work,"' Stanford Law Review 43:6 (July 1991): 1334 .

${ }^{33}$ Yukiko Kimura, Issei: Japanese Immigrants in Hawaii (Honolulu: University of Hawaii Press, 1988) 62.

${ }^{34}$ Kimura, Issei 62.

35 For more information on Japanese migrant clothing see Kawakami, Japanese Immigrant Clothing in Hawaii, I 885-I94I.

${ }^{36}$ Hanahana: An Oral History Anthology of Hawaii's Working People, 157-1 $5^{8 .}$

${ }^{37}$ L. M. Baldwin, "Sheriff's Report, Island of Maui," Report of the Attorney General to the Governor of the Territory of Hawaii, I902 (Honolulu: Hawaiian Gazette, 1903): 23 .

38 Joan Hori, "Japanese Prostitution in Hawaii During the Immigration Period," HJH 15 (1991): 113-124.

39 Ryukichi Kihara, ハワイ日本人史 [Hawaii Nippon-jin Shi/ History of the Hawaii's Japanese] (Tokyo Bunseisha, 1935) 507.

${ }^{40}$ E. G. Hitchcock, "Report of Sheriff of Hawaii," Biennial Report of the Attorney General to the Legislative Assembly of 1892 (Honolulu: R. Grieve, 1892): 20.

${ }^{41}$ L. M. Baldwin, "Sheriff's Report, Island of Maui," Report of the Attorney General, I902 (Honolulu: Hawaiian Gazette, 1903): 23.

${ }^{42}$ L. M. Baldwin, "Sheriff's Report, Island of Maui," Report of the Attorney General, I904 (Honolulu: Hawaiian Gazette, 1905) 23.

${ }^{43}$ James H. Okahata, History of the Japanese in Hawaii (Honolulu: United Japanese Society of Hawaii, 1971) 155; Yuji Ichioka, "Ameyuki-San: Japanese Prostitutes in Nineteenth-Century America," Amerasia Journal 4:1 (1977): 1-2 1.

${ }^{44}$ First Circuit Court of Honolulu Legal Documents Branch, "Mizi Iwamoto, Libellant, vs. Sentaro Iwamoto, Libellee," Case number 3159.

45 First Circuit Court of Honolulu Legal Documents Branch, "Tsuya Ogawa, Libellant, vs. Namahichi Ogawa, Libellee," Case number 3382.

${ }^{46}$ Report of Committee on the Social Evil. Honolulu Social Survey (Honolulu: Honolulu Star Bulletin, Ltd., 1914) 7.

${ }_{47}$ Report of Committee on the Social Evil, 7.

${ }^{48}$ Miyako Kanichi, 娼婦海外流浪記 [Shōfu Kaigai Rurōki/ An Account of Overseas Travels of Prostitutes] (Tokyo: Shanichi Shobo, 1968) 118.

${ }^{49}$ Hawaii (Republic), General Superintendent of the Census, Report of the General Superintendent of the Census, 1896 (Honolulu: Hawaiian Star Press, 1897) 89.

50 "In Darkest Honolulu: Where the Drag-Net of Reform is Needed," PCA, 30 January 1896, 1; Wallace R. Farrington, "A Growing Evil," PCA, zo January 1896, 4 .

51 “Are Women to be Sold?” PCA, 14 May 19oo, 1; “They Are Free: Japanese Procurers All Released,” PCA, 12 May 1900, 6; Yesterdays' Sermons: The Clergy Talk of Needed Reforms," PCA, 3 February 1896, 1.

${ }_{52}$ Okahata, A History of the Japanese in Hawaii 154 .

53 Takie Okumura, Seventy Years of Divine Blessings (Honolulu: n.p., 1939) 22.

${ }^{54}$ Okahata, A History of the Japanese in Hawaii $15^{6 .}$

${ }^{55}$ Susan L. Smith, Japanese American Midwives: Culture, Community, and Health Politics, I880-1950 (Urbana, Illinois: University of Illinois Press, 2005) 117. 
${ }^{56}$ Tanji, Eight Life Stories 5 .

${ }^{57}$ Ethnic Studies Oral History Project, Waialua E Haleiwa: The People Tell Their Story Volume III Filipinos (Honolulu: Ethnic Studies Program University of Hawaii, Manoa, 1977) 33-34.

58 Tanji, Eight Life Stories 13.

59 Tanji, Eight Life Stories 1.

${ }^{60}$ Tanji, Eight Life Stories 11.

${ }^{61}$ Ethnic Studies Oral History Project, Waialua E Haleiwa: The People Tell Their Story Volume VII Koreans and Puerto Ricans (Honolulu: Ethnic Studies Program University of Hawaii, Manoa, 1977) 28.

${ }^{62}$ Smith, Japanese American Midwives 122.

63 “48 Midwives Registered Here,” HA, 1 January 1932, 6.

${ }^{64}$ Ethnic Studies Oral History Project, Waialua $\mathcal{F}^{2}$ Haleiwa: The People Tell Their Story Volume VIII Portuguese (Honolulu: Ethnic Studies Program University of Hawaii, Manoa, 1977) 32.

${ }^{65}$ Ethnic Studies Oral History Project, Waialua \& Haleiwa 33.

66 Tanji, Eight Life Stories 4.

67 Waialua E Haleiwa: The People Tell Their Story Volume VIII Portuguese, 33.

${ }^{68}$ Ethnic Studies Oral History Project, Waialua E Haleiwa: The People Tell Their Story Volume III Filipinos (Honolulu: Ethnic Studies Program University of Hawaii, Manoa, 1977) 34 .

69 Tanji, Eight Life Stories 12.

70 "Mystery Unveiled: Japanese Barberess and Her Methods," PCA, 27 July 1904, 15 .

${ }^{71}$ Yukiko Kimura, "Honolulu Barber Girls-A Study in Culture Conflict," Social Process In Hawaii V (June 1939): 22.

72 According to Kimura, 81 percent of the girls did not go beyond the eighth grade; some left as early as the end of second grade. Kimura reported that only two girls out of eighty-seven barbers had completed high school. Kimura, "Honolulu Barber Girls-A Study in Culture Conflict" 26.

${ }^{73}$ Gary Tachiyama, "Old Japanese Barber Shops," Hawaii Herald, 1 October 1982,14 .

${ }^{74}$ Kimura, "Honolulu Barber Girls-A Study in Culture Conflict" 24.

${ }^{75}$ Kimura, "Honolulu Barber Girls-A Study in Culture Conflict" 24.

${ }^{76}$ Kimura, "Honolulu Barber Girls—A Study in Culture Conflict" 26.

77 Tanji, Eight Life Stories 43.

78 Tanji, Eight Life Stories 42.

79 Tanji, Eight Life Stories 43.

80 Tanji, Eight Life Stories $5^{2}$.

${ }^{81}$ Tanji, Eight Life Stories 9-10.

82 Women Workers in Hawaii’s Pineapple Industry Volume II 901. 